\title{
A comparison of retrofitting methods on nursing faculty building of Andalas University with concrete jacketing and shear wall systems
}

\author{
Fauzan $^{1, *}$, Febrin Anas Ismail ${ }^{1}$, Oswin Dezardo ${ }^{1}$, and Zev Al Jauhari ${ }^{2}$ \\ ${ }^{1}$ Civil Engineering Dept., Andalas University, 25163 Limau Manis, Indonesia \\ ${ }^{2}$ Civil Engineering Dept., Bengkalis State Polytechnic, 28714 Sungai Alam Bengkalis, Indonesia
}

\begin{abstract}
The Nursing Faculty building is one of the buildings that fulfill the administrative eligibility in Andalas University, Padang - Indonesia, which was designed by a building design consultant based on the Indonesian standard code. During the building construction, the concrete quality was found to not to be in accordance with the designed concrete quality and construction was terminated by the owner. A structural evaluation of the building is carried out based on the Indonesia seismic code SNI 2847:2012. The results show that the building is not strong enough to withstand the combination of the loads acting on the structure, especially an earthquake load. Two methods were proposed to retrofit the building; by increasing the dimensions of the cross-section and add reinforcement to the structural elements (jacketing) and by adding some structural wall at the site of the plan with the aim to rigidify the building (shear wall). It is found that the two retrofitting methods are effective in reducing the internal forces and displacement on the building structures and the building is capable of resisting the working loads. Comparing the two retrofitting methods, the concrete jacketing column is more cost-effective than the shear wall method.
\end{abstract}

\section{Introduction}

Andalas University is a great university located in Padang City, West Sumatera Province, Indonesia, which is in the high seismic region. The Nursing Faculty is a new faculty at Andalas University, which was established on the $3^{\text {rd }}$ of August 2012. To fulfil the administrative eligibility, a new Nursing Faculty building was built. The building was planned as a two-story reinforced concrete frame structure. During the construction, it was found that the concrete compressive strength is low $\left(\mathrm{fc}^{\prime}=15 \mathrm{MPa}\right)$, which does not meet the strength requirement that was designed by the design consultant $\left(\mathrm{fc}^{\prime}=20 \mathrm{MPa}\right)$. Also, the construction is apparently poor quality, so that the construction was stopped and it cannot be continued. In order to reduce the loss of life and damage to the building when the earthquake occurs, the performance of the structures must be improved by applying seismic retrofitting methods.

* Corresponding author: fauzan@ft.unand.ac.id; fauzanrn@yahoo.com 
Retrofitting of the building structure proves that a better option should be taken, which are more cost-effective and time-efficient rather than replacement of seismic deficient buildings [1]. Retrofitting can generally be classified into two categories: global and local. The global retrofitting technique targets the seismic resistance of the building by upgrading the structure to resist earthquake-induced forces (modifying the capacity). One of them is adding a shear wall. The shear wall can be introduced in a building with the flat slab or flat plate. A new shear wall should be provided with an adequate foundation $[2,3]$. The local retrofitting technique targets the seismic resistance of a member, which focuses on the reduction of earthquake-induced forces (modifying the demand). One of them is the concrete jacketing to the structural members like beams, columns, beam-column joint, and foundation. Concrete jacketing involves adding a new layer of concrete with longitudinal reinforcement and closely spaced ties. The jacket increases both the flexural strength and the shear strength of the beam or the column. It increases the seismic resistance of the building without any demolition. The lateral load capability, ductility, and stiffness of the building are also improved [4,5].

This paper conducted two alternatives for retrofitting, such as concrete jacketing and adding a shear wall. This study focuses on the seismic evaluation of the existing building structure and retrofitting of a two-story RC building designed by two loads design philosophies i.e. SNI 1726:2012 [6] and SNI 1727:2013 [7], along with a concrete detailing as per SNI 2847:2013 [8].

\section{Methods and analysis}

The proper account of the working loads, properties of material, the systems of structure, and methods of analysis are fundamental factors in the analysis of a structure. The analysis of the existing structure should be carried out based on the existing data obtained from the structure.

\subsection{Building data}

Data related to structural analysis, such as as-built drawings and material properties, were obtained from the design consultant. The plan and front views of the building are shown in Figure 1.

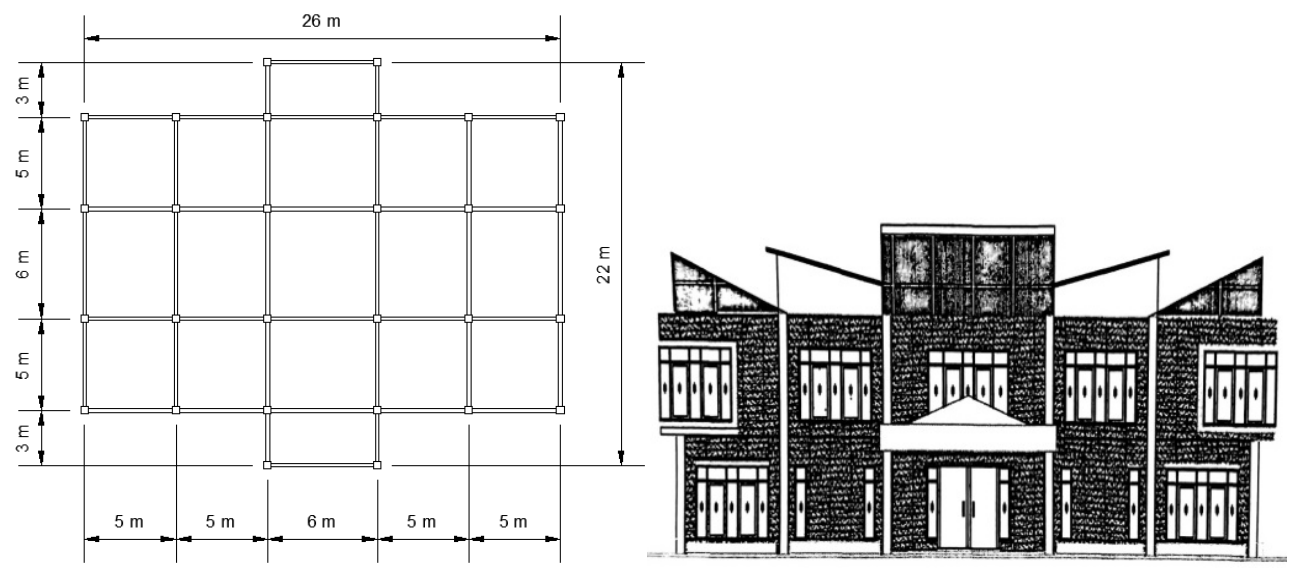

Fig. 1. The plan and front view of the Nursing Faculty Andalas University building. 
To obtain the compressive strength of the existing concrete, the hammer test was performed. The test results show that the average of the existing concrete's compressive strength $\left(f_{\mathrm{c}}{ }^{\prime}\right)$ is $15 \mathrm{MPa}$. While, the number and properties of the reinforcement bar obtained from the data of the design consultant has a yield strength $\left(f_{y}\right)$ of $400 \mathrm{MPa}$ and $240 \mathrm{MPa}$ for bending and shear reinforcement, respectively. In seismic evaluation process of the existing building, the model should closely represent the actual structure. This model was achieved by using an as-built drawing, as follows:

- Number of the storeys: 2

- Height of the building: $8 \mathrm{~m}$

- Column: K1 $(40 \times 40) \mathrm{cm}^{2}$ and K2 $(25 \times 25) \mathrm{cm}^{2}$

- Beam: B1 (30 x 50) $\mathrm{cm}^{2}$; B2 $(20 \times 30) \mathrm{cm}^{2}$; and B3 $(20 \times 25) \mathrm{cm}^{2}$

- Length $\mathrm{x}$ width of the building: $26 \mathrm{~m}$ x $22 \mathrm{~m}$

- The thickness of slab: $12 \mathrm{~cm}$.

\subsection{Loads}

The loads that accounted for the feasibility of the existing structure consists of dead, live, and earthquake loads. The dead and live loads were calculated based on SNI 1727:2013. The earthquake load uses the response spectra analysis (dynamic analysis) referring to the Indonesian Public Work Department data [9], which has been adapted in SNI 1726:2012.

The spectrum design is a representation of ground motion due to earthquake vibrations that have occurred in a location. The building is located in the area of Limau Manis with medium soil condition. Hence, the response data can be seen in Figure 2. The required parameters to determine the earthquake load are as follows: the earthquake reduction factor (R) is 8 , and the seismic importance factor $\left(I_{e}\right)$ is 1.5 .

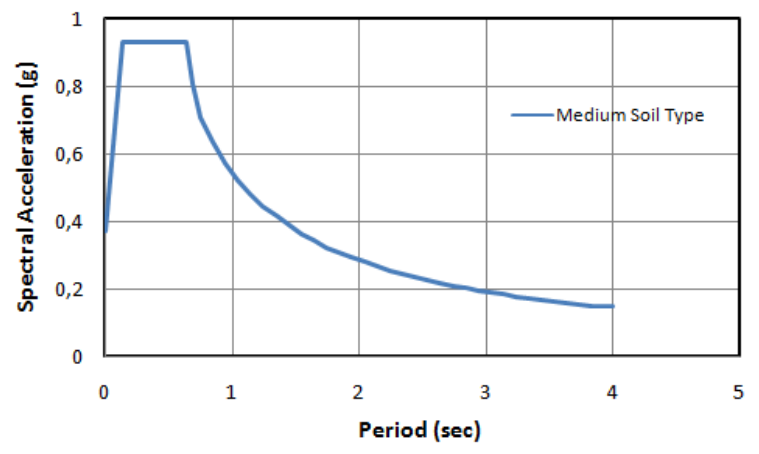

Fig. 2. Earthquake response spectra design for Padang City (medium soil type) [9]

\subsection{Evaluation of existing building structure}

The structure of the Nursing Faculty building is modelled and analyzed by using ETABS v9.7.1 software [10]. After that, the analysis of cross-sectional capacity in the structural element is done by comparing the maximum internal forces.

\subsubsection{Load-bearing capacity of the existing structure}

The analysis of the capacity of the beam uses the largest cross-section and the longest span one, and then the capacity is compared to the internal force that occurred due to the working loads. From Table 1, it is shown that the beam can resist the working loads. 
Table 1. Flexural and shear capacities on the existing beam.

\begin{tabular}{|c|c|c|c|c|c|c|c|c|c|}
\hline \multirow{2}{*}{ Story } & \multirow{2}{*}{$\begin{array}{c}\text { Cross } \\
\text { Section } \\
\text { b x h } \\
\left(\mathbf{m m}^{2}\right) \\
\end{array}$} & \multicolumn{2}{|c|}{$\begin{array}{c}\text { Reinforcement } \\
\text { Installed }\end{array}$} & \multirow{2}{*}{$\underset{(\mathbf{k N m})}{\mathrm{Mu}}$} & \multirow{2}{*}{$\begin{array}{c}\text { Mn } \\
(\mathbf{k N m})\end{array}$} & \multirow{2}{*}{$\begin{array}{c}\text { Mu } \\
\leq \\
\mathbf{M n}\end{array}$} & \multirow{2}{*}{$\begin{array}{c}\mathbf{V u} \\
(\mathbf{k N})\end{array}$} & \multirow{2}{*}{$\begin{array}{l}\text { Vn } \\
(\mathbf{k N})\end{array}$} & \multirow{2}{*}{$\begin{array}{c}V u \\
\leq \\
V n\end{array}$} \\
\hline & & Tens. & Comp. & & & & & & \\
\hline $1^{\text {st }}$ & $300 \times 500$ & $5 \mathrm{D} 16$ & $3 \mathrm{D} 16$ & 62,70 & 138,45 & OK & 89,22 & 298,39 & OK \\
\hline $2^{\text {nd }}$ & $300 \times 500$ & $5 \mathrm{D} 16$ & $3 \mathrm{D} 16$ & 61,83 & 138,45 & OK & 23,45 & 298,39 & OK \\
\hline
\end{tabular}

Based on the analysis of the column capacity using a P-M interaction diagram (a visual representation of the combined loads; bending and axial that will cause the column to fail), as seen in Figure 3 and Table 2, the bending capacity of the columns on the $1^{\text {st }}$ floor is not capable of carrying the working loads, while the column shear capacity is capable of carrying the shear force.

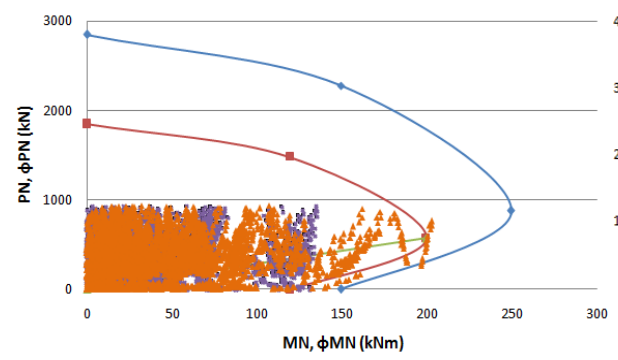

(a)

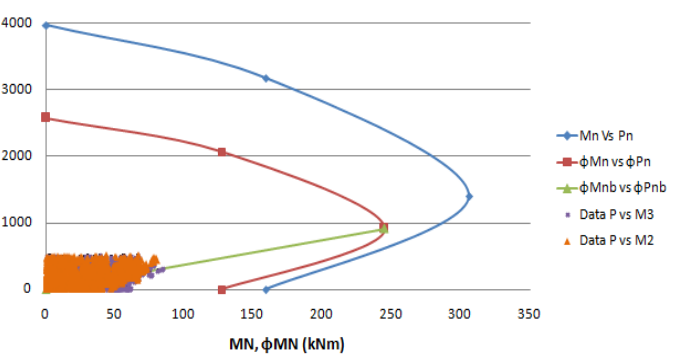

(b)

Fig. 3. P-M interaction diagram of existing column in (a) $1^{\text {st }}$ floor and (b) $2^{\text {nd }}$ floor.

Table 2. Flexural and shear capacity on the existing column.

\begin{tabular}{|c|c|c|c|c|c|c|c|c|c|}
\hline \multirow{2}{*}{ Story } & \multirow{2}{*}{$\begin{array}{c}\text { Cross } \\
\text { Section } \\
\left(\mathbf{m m}^{2}\right)\end{array}$} & \multicolumn{2}{|c|}{$\begin{array}{c}\text { Reinforcement } \\
\text { Installed }\end{array}$} & \multirow{2}{*}{$\begin{array}{c}\text { Mu } \\
(\mathbf{k N m})\end{array}$} & \multirow{2}{*}{$\begin{array}{c}\text { Mn } \\
(\mathbf{k N m})\end{array}$} & \multirow{2}{*}{$\begin{array}{c}\text { Mu } \\
\leq \\
\text { Mn }\end{array}$} & \multirow{2}{*}{$\begin{array}{l}\text { Vu } \\
(\mathbf{k N})\end{array}$} & \multirow{2}{*}{$\begin{array}{l}\text { Vn } \\
(\mathbf{k N})\end{array}$} & \multirow{2}{*}{$\begin{array}{c}\mathrm{Vu} \\
\leq \\
\mathbf{V n}\end{array}$} \\
\hline & & Flex. & Shear & & & & & & \\
\hline $1^{\text {st }}$ & $400 \times 400$ & $12 \mathrm{D} 16$ & $10-100$ & 202,56 & 119,42 & NOT & 74,80 & 1993 & OK \\
\hline $2^{\text {nd }}$ & $400 \times 400$ & $12 \mathrm{D} 16$ & $10-100$ & 83,08 & 126,70 & $\mathrm{OK}$ & 45,31 & 2193 & OK \\
\hline
\end{tabular}

\subsubsection{Inter-story drift of the existing structure}

Table 3. Inter-story drift on the existing building.

\begin{tabular}{|c|c|c|c|c|c|c|c|c|c|}
\hline Story & $\begin{array}{c}\mathbf{\Delta a} \\
(\mathbf{m m})\end{array}$ & $\begin{array}{c}\text { Disp. } \\
\mathbf{X} \\
(\mathbf{m m})\end{array}$ & $\begin{array}{c}\text { Drift } \\
\mathbf{X} \\
(\mathbf{m m})\end{array}$ & $\begin{array}{c}\mathbf{\Delta s} \mathbf{Y} \\
(\mathbf{m m})\end{array}$ & $\begin{array}{c}\mathbf{\Delta s} \leq \\
\mathbf{\Delta a}\end{array}$ & $\begin{array}{c}\text { Disp. } \\
\mathbf{Y}\end{array}$ & $\begin{array}{c}\text { Drift } \\
\mathbf{Y}\end{array}$ & $\begin{array}{c}\mathbf{\Delta} \mathbf{Y} \\
(\mathbf{m m})\end{array}$ & $\begin{array}{c}\Delta \mathbf{s} \leq \\
\mathbf{( m m})\end{array}$ \\
\hline $1^{\text {st }}$ & 46,15 & 5,20 & 5,20 & 19,06 & OK & 5,64 & 5,64 & 20,68 & OK \\
\hline $2^{\text {nd }}$ & 46,15 & 11,27 & 6,07 & 22,26 & OK & 11,97 & 6,33 & 23,21 & OK \\
\hline
\end{tabular}

Based on the calculation of inter-story drift, as shown in Table 3, it can be seen that the amount of inter-story drift in the $\mathrm{X}$ and $\mathrm{Y}$ directions meets the required allowable drift. 


\subsubsection{Foundation of the existing structure}

The existing structure uses a footprint foundation with $1.6 \mathrm{~m}$ depth and $1.2 \mathrm{~m}$ length. Results of the analysis show that the foundation has enough capacity to resist all loads applied in the building structure. The calculation of the foundation capacity is shown in Table 4.

Table 4. The calculation of foundation capacity.

\begin{tabular}{|c|c|c|}
\hline & Formula & Value \\
\hline $\mathrm{q}_{\mathrm{c}}$ & data of sondir & $0.8 \mathrm{~B}$ and $0.7 \mathrm{~B}$ \\
\hline $\mathrm{q}_{\mathrm{c} \text { average }}$ & $\left(\Sigma \mathrm{q}_{\mathrm{c}}\right) / \mathrm{n}$ & $2950 \mathrm{kN} / \mathrm{m}^{2}$ \\
\hline $\mathrm{Q}_{\text {full }}$ & $\mathrm{q}_{\mathrm{c} \text { average }} / \mathrm{SF}$ & $983.33 \mathrm{kN}$ \\
\hline $\mathrm{Quult}$ & ETABS & $674.47 \mathrm{kN}$ \\
\hline \multicolumn{3}{|c|}{ Check: $\mathrm{Q}_{\text {full }} \geq \mathrm{Quult}_{\mathrm{n}} \ldots(\mathrm{OK})$} \\
\hline
\end{tabular}

From the result of the performance evaluation and structural strength to SNI 1726:2012, the building structure was unable to withstand the working load, so that the building structure should be retrofitted. From the analysis of the structure by using the latest seismic code, the elements that need strengthening are the existing column on the $1^{\text {st }}$ floor.

\section{Proposed retrofitting methods for the building structure}

\subsection{Retrofitting structure with concrete column jacketing}

\subsubsection{Data and modelling of concrete jacketing}

Concrete jacketing of columns is a retrofitting method by adding concrete with longitudinal and transverse reinforcement around the existing columns. This retrofitting method improves the axial and shear strength of columns while there is no significant change in the flexural strength of columns and the strength of the beam-column joints $[11,12]$.

Table 5. Cross-section of column jacketing.

\begin{tabular}{|c|c|c|}
\hline \multirow{2}{*}{ Column } & Existing & Retrofitting \\
\hline & $400 \times 1$. & \\
\hline Cross section & $400 \mathrm{~mm}^{2}$ & $500 \times 500 \mathrm{~mm}^{2}$ \\
\hline Flexural reinforcement bar & $12 \mathrm{D} 16$ & $24 \mathrm{D} 16$ \\
\hline Shear reinforcement bar & $\varnothing 10-100 \mathrm{~mm}$ & $\varnothing 10-100 \mathrm{~mm}$ \\
\hline
\end{tabular}

There are two main purposes of jacketing of columns, i.e., to increase the shear capacity of columns and to improve the column's flexural strength by the longitudinal steel of the jacket made continuous through the slab system which is anchored with the foundation. The adding of concrete column jacketing in this study is drawn in Table 5. Modelling the column in concrete jacketing on ETABS is performed by enlarging the cross-sectional dimension and 
adding the reinforcement in accordance with the planned amount for the reinforcing column as shown in Figure 4.
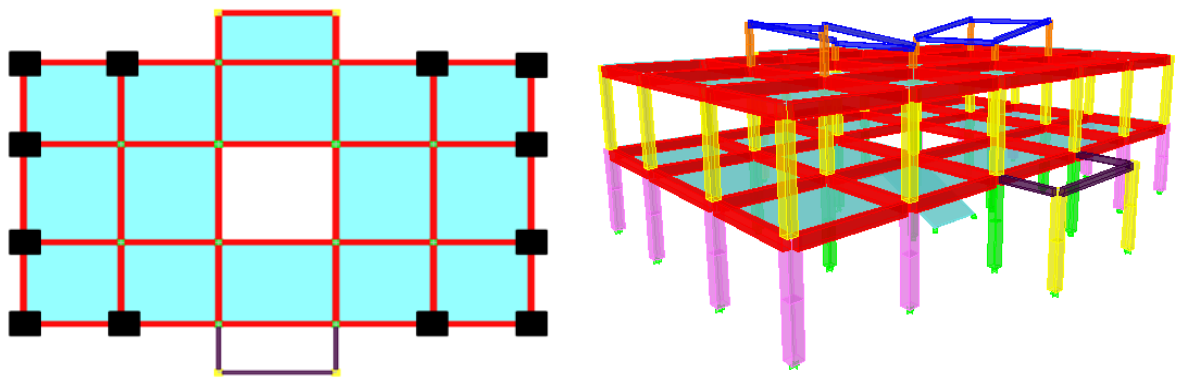

Fig. 4. Location of column jacketing construction and the 3D modelling of the building.

\subsubsection{Internal forces and load-bearing capacity}

Figure 5 and Table 6 show the P-M interaction diagram and the recapitulation of column capacity after adding the concrete jacketing. The jacketed column leads to the internal force reduction and also make the bending and axial capacity of the $1^{\text {st }}$ floor capable of resisting the working loads. The inter-story drifts of the retrofitted structure using concrete jacketing are in accordance with the required permit limit of the allowable inter-story drift in SNI 1726:2012, as seen in Table 7.

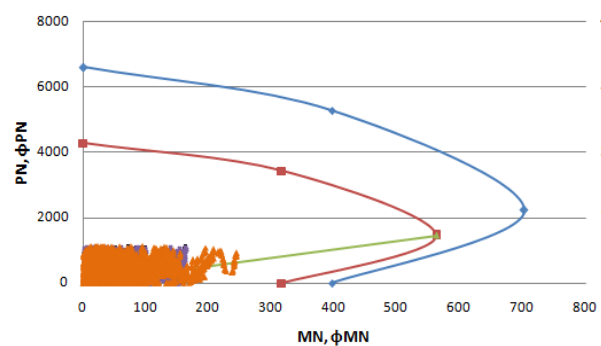

(a)

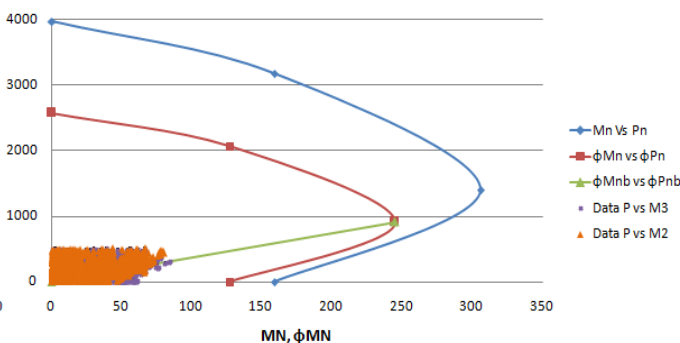

(b)

Fig. 5. P-M interaction diagram of column jacketing in the (a) $1^{\text {st }}$ floor and (b) $2^{\text {nd }}$ floor.

Table 6. Flexural and shear capacity of the column after concrete jacketing.

\begin{tabular}{|c|c|c|c|c|c|c|c|c|c|}
\hline \multirow{2}{*}{ Story } & \multirow{2}{*}{$\begin{array}{c}\text { Cross } \\
\text { Section } \\
\left(\mathbf{m m}^{2}\right)\end{array}$} & \multicolumn{2}{|c|}{$\begin{array}{c}\text { Reinforcement } \\
\text { Installed }\end{array}$} & \multirow{2}{*}{$\begin{array}{c}\text { Mu } \\
(\mathbf{k N m})\end{array}$} & \multirow{2}{*}{$\begin{array}{c}\text { Mn } \\
(\mathbf{k N m})\end{array}$} & \multirow{2}{*}{$\begin{array}{c}\mathbf{M u} \\
\leq \\
\mathbf{M n}\end{array}$} & \multirow{2}{*}{$\begin{array}{l}\mathbf{V u} \\
(\mathbf{k N})\end{array}$} & \multirow{2}{*}{$\begin{array}{l}\text { Vn } \\
(\mathbf{k N})\end{array}$} & \multirow{2}{*}{$\begin{array}{l}\mathrm{Vu} \\
\leq \\
\mathrm{Vn}\end{array}$} \\
\hline & & Flex. & Shear & & & & & & \\
\hline $1^{\text {st }}$ & $500 \times 500$ & $24 \mathrm{D} 16$ & $10-100$ & 243,08 & 315,88 & OK & 92,10 & 2443 & $\mathrm{OK}$ \\
\hline $2^{\text {nd }}$ & $400 \times 400$ & $12 \mathrm{D} 16$ & $10-100$ & 83,08 & 126,70 & OK & 45,31 & 2193 & $\mathrm{OK}$ \\
\hline
\end{tabular}

Table 7. Inter-story drift of the building with column concrete jacketing.

\begin{tabular}{|c|c|c|c|c|c|c|c|c|c|}
\hline Story & $\begin{array}{c}\Delta \mathbf{a} \\
(\mathbf{m m})\end{array}$ & $\begin{array}{c}\text { Disp. } \\
\mathbf{X} \\
(\mathrm{mm})\end{array}$ & $\begin{array}{c}\text { Drift } \\
\mathbf{X} \\
(\mathrm{mm})\end{array}$ & $\begin{array}{c}\Delta \mathbf{s ~ X} \\
(\mathbf{m m})\end{array}$ & $\begin{array}{c}\Delta \mathbf{s} \\
\leq \\
\Delta \mathbf{a} \\
\end{array}$ & $\begin{array}{c}\text { Disp. } \\
\mathbf{Y} \\
(\mathbf{m m})\end{array}$ & $\begin{array}{c}\text { Drift } \\
\mathbf{Y} \\
(\mathbf{m m})\end{array}$ & $\begin{array}{c}\Delta \mathbf{s ~ Y} \\
(\mathbf{m m})\end{array}$ & $\begin{array}{c}\Delta \mathbf{s} \leq \\
\Delta \mathbf{a}\end{array}$ \\
\hline $1^{\mathrm{st}}$ & 46,15 & 4,51 & 4,51 & 16,54 & OK & 4,90 & 4,90 & 17,97 & $\mathrm{OK}$ \\
\hline $2^{\text {nd }}$ & 46,15 & 10,54 & 6,03 & 22,11 & $\mathrm{OK}$ & 11,01 & 6,11 & 22,40 & $\mathrm{OK}$ \\
\hline
\end{tabular}


The addition of jacketing to the column structure gives an increase in the column capacity. The largest percentage increase in the capacity design was around $165 \%, 23 \%$, and $132 \%$ for bending moment, shear, and axial, respectively. The decrease of displacements in the retrofitting structure compared to the existing structure is about $13 \%$ both for the $\mathrm{X}$ and $\mathrm{Y}$ directions.

\subsection{Retrofitting structure with shear wall}

\subsubsection{Data and modelling of shear wall}

Adding structural walls is one of the most common structure-level retrofitting methods to strengthen existing structures. This approach is effective for controlling global lateral drifts and for reducing damage to frame members $[13,14]$. In this study, the shear wall was placed only in the corner of the building on the $1^{\text {st }}$ floor. As seen in Figure 6 , the shear wall used had:

- Length $\mathrm{x}$ height $\mathrm{x}$ thickness: $5 \mathrm{~m}$ x $4 \mathrm{~m} \times 20 \mathrm{~cm}$,

- The compressive strength of concrete (f'c): $25 \mathrm{MPa}$,

- The yield strength of reinforcement bar D-13 mm: $400 \mathrm{MPa}$.

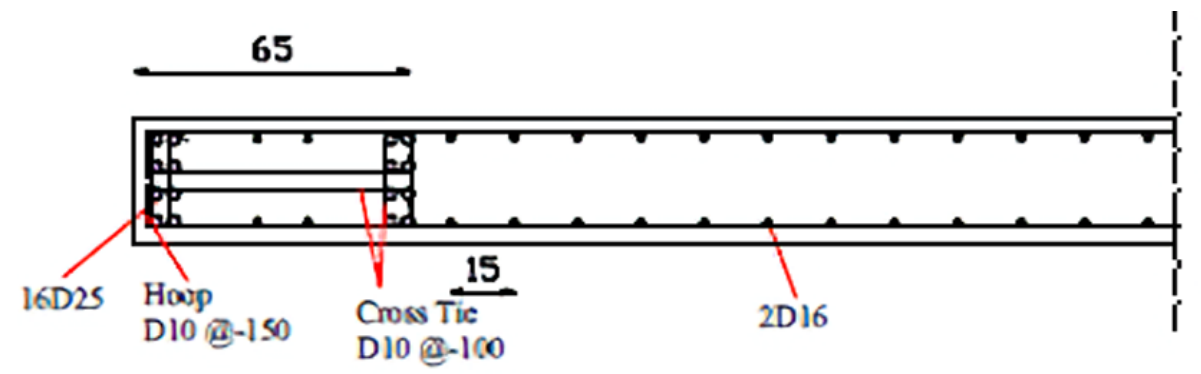

Fig. 6. The detail of reinforcement bar of the shear wall.

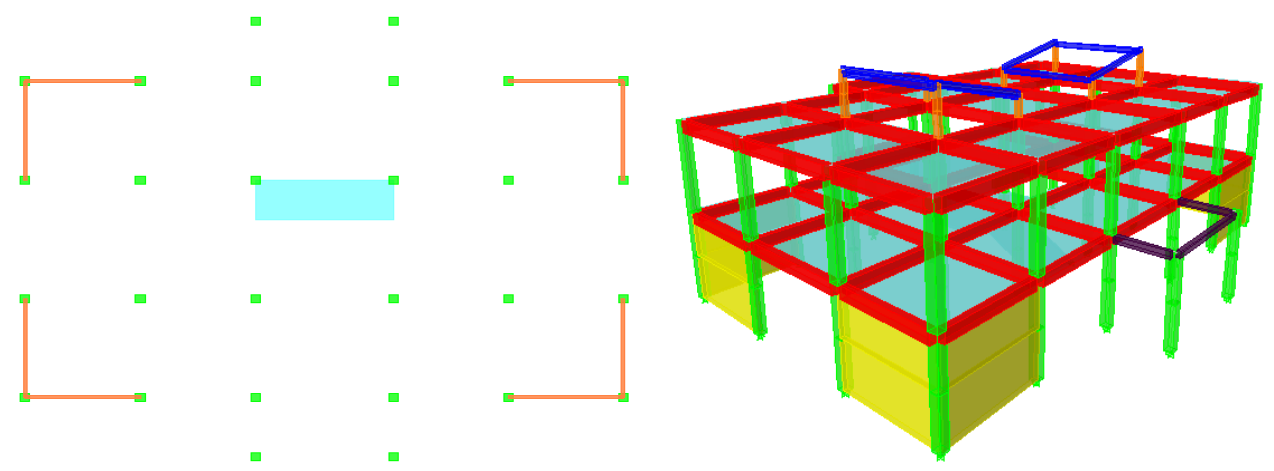

Fig. 7. Location of shear wall placement and the 3D modelling of the building.

The cross-section and detailing reinforcement of the shear wall are shown in Figure 6. The shear wall thickness used was calculated based on SNI 2847:2002, where $0.14 \mathrm{~m}<\mathrm{t}<$ $\mathrm{h} / 24 \mathrm{~m}$ and found that the optimum thickness of the shear wall is $20 \mathrm{~cm}$ [15]. Figure 7 shows the location of the shear wall placement as a 3D model of the building after adding the shear wall. 


\subsubsection{Internal forces and load-bearing capacity}

The addition of the shear wall to the structure gives a decrease of internal forces in the columns. The largest percentage of decline was around $83 \%, 48 \%$, and $6 \%$ for bending moment, shear, and axial forces, respectively. The decrease of displacements between the existing and retrofitted structure is around $84 \%$ and $90 \%$ for the $\mathrm{X}$ and $\mathrm{Y}$ directions, respectively.

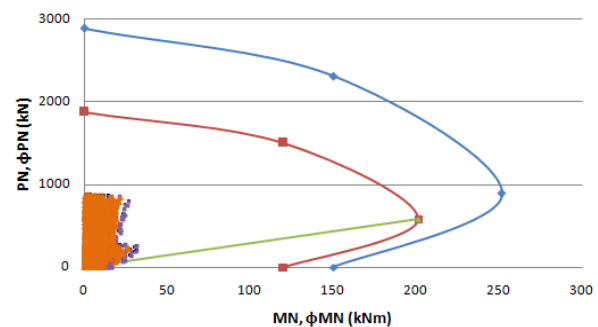

(a)

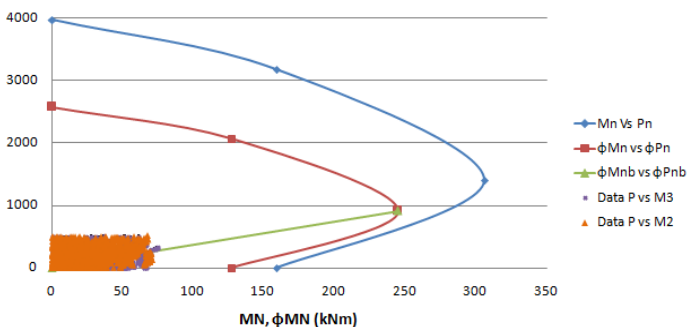

(b)

Fig. 8. P-M interaction diagram of a column in the (a) $1^{\text {st }}$ floor and (b) $2^{\text {nd }}$ floor after adding the shear wall.

Figure 8 and Table 8 show the P-M interaction diagram and the recapitulation of column capacity after concrete column jacketing. The internal force reduction in the column leads to the bending capacity of the $1^{\text {st }}$ floor columns capable of resisting the working loads. The inter-story drift of the structure by adding shear wall systems are in accordance with the allowable limit required by SNI 1726:2012, as seen in Table 9.

Table 8. Shear capacity on the column after adding the shear wall.

\begin{tabular}{|c|c|c|c|c|c|c|}
\hline \multirow{2}{*}{ Story } & \multirow{2}{*}{$\begin{array}{c}\text { Cross Section } \\
\left(\mathbf{m m}^{2}\right)\end{array}$} & \multicolumn{2}{|c|}{$\begin{array}{l}\text { Reinforcement } \\
\text { Installed }\end{array}$} & \multirow{2}{*}{$\underset{(\mathbf{k N})}{\mathbf{V u}}$} & \multirow{2}{*}{$\begin{array}{l}\mathbf{V n} \\
(\mathbf{k N})\end{array}$} & \multirow{2}{*}{$\underset{\mathbf{V u}}{\mathbf{V u}} \leq$} \\
\hline & & $\begin{array}{c}\text { Diameter } \\
(\mathrm{mm})\end{array}$ & $\begin{array}{l}\text { Space } \\
(\mathbf{m m})\end{array}$ & & & \\
\hline $1^{\text {st }}$ & $400 \times 400$ & 10 & 100 & 19,71 & 1933,66 & $\mathrm{OK}$ \\
\hline $2^{\text {nd }}$ & $400 \times 400$ & 10 & 100 & 42,07 & 2193,66 & $\mathrm{OK}$ \\
\hline
\end{tabular}

Table 9. Inter-story drift on the building after adding the shear wall.

\begin{tabular}{|c|c|c|c|c|c|c|c|c|c|}
\hline Story & $\begin{array}{c}\Delta \mathbf{a} \\
(\mathbf{m m})\end{array}$ & $\begin{array}{c}\text { Disp. } \\
\mathbf{X} \\
(\mathbf{m m})\end{array}$ & $\begin{array}{c}\text { Drift } \\
\mathbf{X} \\
(\mathbf{m m})\end{array}$ & $\begin{array}{c}\mathbf{\Delta} \mathbf{X} \\
\mathbf{( m m})\end{array}$ & $\begin{array}{c}\Delta \mathbf{s} \\
\mathbf{\Delta a}\end{array}$ & $\begin{array}{c}\text { Disp. } \\
\mathbf{Y} \\
(\mathbf{m m})\end{array}$ & $\begin{array}{c}\text { Drift } \\
\mathbf{Y} \\
(\mathbf{m m})\end{array}$ & $\begin{array}{c}\Delta \mathbf{s} \mathbf{Y} \\
(\mathbf{m m})\end{array}$ & $\begin{array}{c}\Delta \mathbf{s} \leq \\
\mathbf{\Delta a}\end{array}$ \\
\hline $1^{\text {st }}$ & 46,15 & 0,83 & 0,83 & 3,04 & $\mathrm{OK}$ & 0,55 & 0,55 & 2,02 & $\mathrm{OK}$ \\
\hline $2^{\text {nd }}$ & 46,15 & 4,41 & 3,58 & 13,12 & $\mathrm{OK}$ & 4,67 & 4,12 & 15,11 & $\mathrm{OK}$ \\
\hline
\end{tabular}

\subsection{The comparison of retrofitting cost}

Not only does retrofitting have the capability to reduce the working load but also the required cost is a consideration in determining which retrofitting method is the best to use. From the two retrofitting alternatives, the jacketing method requires IDR. 149,637,400 and the shear wall method costs IDR 249,650,800. So, the concrete column jacketing retrofitting method becomes a more economical and easy-to-use alternative than the retrofitting by adding the shear wall. The comparison of BOQ for the two retrofitted methods is shown in Table 10 [16]. 
Table 10. The comparison of BOQ on the two retrofitting methods.

\begin{tabular}{|c|c|c|c|c|c|c|}
\hline Method & Item of Work & Unit & Vol. & $\begin{array}{l}\text { Unit Price } \\
\text { of Work } \\
\text { (IDR) }\end{array}$ & $\begin{array}{l}\text { BOQ } \\
\text { (IDR) }\end{array}$ & $\begin{array}{c}\text { Total BOQ } \\
+10 \% \text { TAX } \\
\text { (IDR) }\end{array}$ \\
\hline \multirow{3}{*}{$\begin{array}{l}\text { Concrete } \\
\text { Jacketing }\end{array}$} & $\begin{array}{l}\text { Demolition of } \\
\text { Concrete Cover }\end{array}$ & $\mathrm{m}^{3}$ & 2.76 & 519,621 & $1,436,649$ & \multirow{3}{*}{$149,637,400$} \\
\hline & $\begin{array}{l}\text { Giving the Concrete } \\
\text { Glue }\end{array}$ & $\mathrm{m}^{2}$ & 61.44 & 42,571 & $2,615,563$ & \\
\hline & $\begin{array}{l}\text { Work on Reinforced } \\
\text { Concrete Column } \\
50 \times 50\end{array}$ & $\mathrm{~m}^{3}$ & 7.09 & $18,628,854$ & $131,981,699$ & \\
\hline \multirow{2}{*}{ Shear Wall } & $\begin{array}{c}\text { Work on Reinforced } \\
\text { Concrete Shear } \\
\text { Wall }\end{array}$ & $\mathrm{m}^{3}$ & 24.00 & $11,122,699$ & $266,944,776$ & \multirow{2}{*}{$294,650,800$} \\
\hline & $\begin{array}{l}\text { Giving the Concrete } \\
\text { Glue }\end{array}$ & $\mathrm{m}^{2}$ & 21.60 & 42,571 & 919,543 & \\
\hline
\end{tabular}

Note: 1 US $\$=14,000$ Indonesian Rupiah (IDR)

\section{Conclusions}

Based on the structural analysis of Nursing Faculty - Andalas University building by using SNI 1726:2012, these conclusions could be drawn:

1. The bending capacity of the columns on the $1^{\text {st }}$ floor is not capable of carrying the working loads from the internal forces when it exceeds the P-M interaction diagram, while the beam capacity and the inter-story drift are safe from the limit standard. The building structure should be retrofitted.

2. There are two types of retrofitting presented in the paper that were conducted in the existing building, concrete jacketing to the columns (local retrofit) and adding a shear wall (global retrofit). All the retrofitting methods lead to a more resistant structure, reducing the seismic risks: lateral displacements decreased, while bending moment and shear force capacities significantly increased.

3. Retrofitting with concrete column jacketing increased the load-bearing capacity of the column, by around $165 \%, 23 \%$, and $132 \%$ for bending moment, shear, and axial forces, respectively. Furthermore, it reduced the building displacement by around $13 \%$ in both the $\mathrm{X}$ and $\mathrm{Y}$ directions.

4. Retrofitting with the shear wall does not increase the capacity of the column, but it reduces the internal forces in the column by around $83 \%, 48 \%$, and $6 \%$ for bending moment, shear, and axial forces, respectively. Positively, the decrease in the building displacement has occurred about $84 \%$ and $90 \%$ in both the $\mathrm{X}$ and $\mathrm{Y}$ directions, respectively.

5. Considering the cost and the ease of the construction, the retrofitting with column jacketing is recommended to be applied to the Nursing Faculty - Andalas University building.

\section{References}

1. S.D.V.S.N. Rao, J. Vikranth, Promotion of Seismic Retrofitting for Existing Low Earthquake Resistant Structures, Int. J. of Eng. Research and Applications, Vol. 3, Issue 6, pp. 1850-1855 (2013) 
2. N. Gupta, P. Dhiman, A. Dhiman, Design and Detailing of RC Jacketting for Concrete Columns, J. of Mech. and Civil Eng. (IOSR- JMCE), pp. 54-58 (2015)

3. J. E. Woods, Seismic Retrofit of Deficient Reinforced Concrete Shear Walls using Fibrereinforced Polymer Sheets: Experimental Study and Anchor Design, A thesis Master of Applied Science, (Carleton University, 2014)

4. M. Dubey, N. Singla, V.S. Batra, Increase in Ultimate Load and Yield Load of Beam Column Joint after Retrofitting, Int. J. of Eng. Development and Research (IJEDR), Vol. 3, Issue 1, pp. 428-433 (2015)

5. A. Sichko and H. Sezen, Review of Methods for Reinforced Concrete Column Retrofit, Conference on Smart Monitoring, Assessment and Rehabilitation of Civil Structures (2017)

6. National Standardization Agency of Indonesia, Design Method of Earthquake Resistance for Buildings and Other Structures SNI 1726:2012, Jakarta, Indonesia (2012)

7. National Standardization Agency of Indonesia, Minimum load for the design of buildings and other structures SNI 1727:2013, Jakarta, Indonesia (2013)

8. National Standardization Agency of Indonesia, Structural Concrete Requiremnets for Building SNI 2847-2013, Jakarta, Indonesia (2013)

9. http://puskim.pu.go.id/Aplikasi/desain_spektra_indonesia_2011/ (2018)

10. Computers and Structures Inc., Manual ETABS (Integrated Building Design Software), California, USA (2016)

11. J. D. Gaitan, Retrofit of Reinforced Concrete Columns, Honors Thesis, The Ohio State University (2017)

12. S. Pravin, B. Waghmare, Materials and Jacketing Technique for Retrofitting of Structures, Int. J. of Advanced Eng. Research and Studies (IJAERS), Vol. 1, Issue 1, pp. 15-19 (2011)

13. S. Anshuman, D. Bhunia, B. Ramjiyani, Solution of Shear Wall Location in Multi-Story Building, IJSCE Vol. 2, No. 2 (Civil Engineering Group, BITS Pilani, India, (2011)

14. Y. Riyad, B. Kissi, I. Mrani, M.A. Parron, R.C.M. Dolores, Seismic Retrofitting: Reinforced concrete shear wall versus CFRP reinforced concrete using pushover analysis, J. of Materials and Eng. Structures, Vol. 3, pp. 181-195 (2016)

15. National Standardization Agency of Indonesia, Procedures of concrete structures design for buildings SNI 2847:2002, Jakarta, Indonesia (2002)

16. Public Works Department of Padang City, Work Unit Price Quarter I 2018, Indonesia (2018) 